\title{
Degradation Analysis of a Rooftop Solar Photovoltaic System-A Case Study
}

\author{
Sheeraz Kirmani', Mohammad Kalimullah ${ }^{2}$ \\ Department of Electrical Engineering, Jamia Millia Islamia (A Central University), New Delhi, India \\ Email: kalimmohammad@yahoo.com
}

How to cite this paper: Kirmani, S. and Kalimullah, M. (2017) Degradation Analysis of a Rooftop Solar Photovoltaic System-A Case Study. Smart Grid and Renewable Energy, 8, 212-219. https://doi.org/10.4236/sgre.2017.86014

Received: April 7, 2017

Accepted: June 27, 2017

Published: June 30, 2017

Copyright ( $) 2017$ by authors and Scientific Research Publishing Inc. This work is licensed under the Creative Commons Attribution International License (CC BY 4.0).

http://creativecommons.org/licenses/by/4.0/

(c) (i) Open Access

\begin{abstract}
The solar photovoltaic (PV) market has grown very rapidly throughout the past 15 years and is quickly becoming an international, non-subsidized market with increased demand for performance certainty. An increasing number of studies analyze long-term monitoring data to determine degradation rates, or "rates of change" (RoCs). Analyses of long-term monitoring data give insight in the performance of PV power plants over time, but are found to be sensitive to uncertainties, especially those related to irradiance measurements using silicon reference cells. The case study analysis shows, however, that the RoCs are much lower if reference cells are adjusted for soiling, drifting and sensor replacements or if satellite irradiance data is used. This indicates that the impact of biased irradiance data should not be underestimated. It was also found, that the distribution of RoCs is strongly influenced by the age and size of the selected systems, underlining the importance of system selection. The case study analysis indicates that crystalline silicon PV systems operating for $8+$ years are expected to show a "rate of change" of $-0.5 \%$ per year or fewer. In this paper the 15-minute data has been collected from a solar photovoltaic generating station installed on the roof of engineering college building and efficiency/degradation of solar panels have been analyzed and reported.
\end{abstract}

\section{Keywords}

Degradation, Drift, Irradiance, Rates of Change, Silicon Reference Cell

\section{Introduction}

The conversion of sunlight to electricity takes place within the solar cells. Crystalline silicon semiconductor is manufactured by a silicon purification process, ingot fabrication, wafer slicing, etching and doping which finally forms a PNP

\footnotetext{
${ }^{1}$ Assistant Professor.

${ }^{2}$ Research Scholar.
} 
junction that traps photons, resulting in the release of electrons within the junction barrier, thereby creating a current flow. This cell has efficiency in the range of $11 \%-18 \%$. This cell is also very stable in chemical structure and is very durable. The advantage of this cell is its efficiency, more than other product but the price is quite high because it was creating from pure silicon material. Solar cells do not degrade easily if they are made from crystalline silicon [1] [2]. The robust design of solar modules combined with the absence of moving parts makes solar modules also very durable. However, modules seem to experience some degradation over time. The degradation will differ from cell to cell, module to module, etc., hence it is more useful to talk about a population of degrading modules than of the degradation of an entire system. Most causes for performance loss can be associated with the module package but some degradation of the semiconductor device cannot be excluded [3] [4] [5]. Potential induced degradation (PID) can reduce the efficiency of a PV module. This article provides insights on PID, including how this degradation process develops, the conditions that make PV systems prone to it, its effects and the methods to correct or prevent it. PID is a process that occurs in PV cells when the system has a negative potential relative to the ground. Although it is a relatively new concept and is not widely understood, techniques already exist to minimize its undesirable effects. The prevention of these adverse effects mainly involves changes in the material used and the system design. However, for systems already affected by PID or for those susceptible to it, a device has been developed that reverses the polarity of the array, forcing the negative charge out of the module. In the past five years, the global solar PV capacity has grown at the average rate of over $50 \%$ a year. In addition, as module and associated costs have decreased, PV systems and solar farms have become larger. Over this period, a considerable number of reports amongst the solar community have emerged about unexplained power losses. Eventually, the cause of these was identified as PID. The explanation is simple: for these large installations, a large number of solar modules are required. Once the modules are connected in series, the systems operate at a high voltage. These are the conditions in which PID can occur. It is now realized that the environment, module material and system design are also related to the degradation process [6] [7] [8] [9] (Figures 1-3).

When a PV system operates at high voltage, i.e., $>1000 \mathrm{~V}$, a considerable potential difference is established between the solar cell and the frame. This means

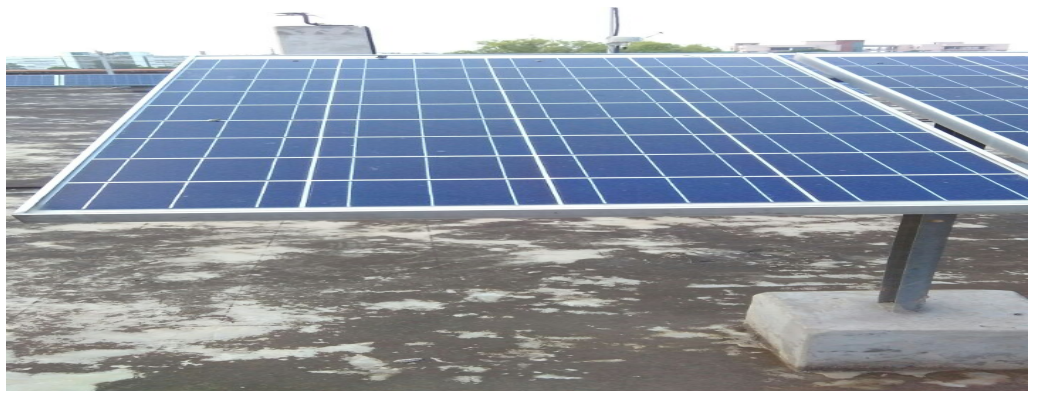

Figure 1. Monocrystalline silicon. 


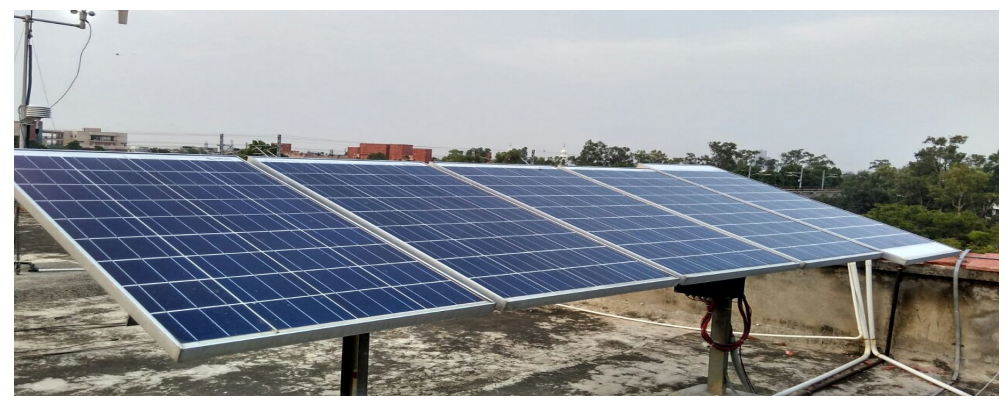

Figure 2. Polycrystalline silicon.

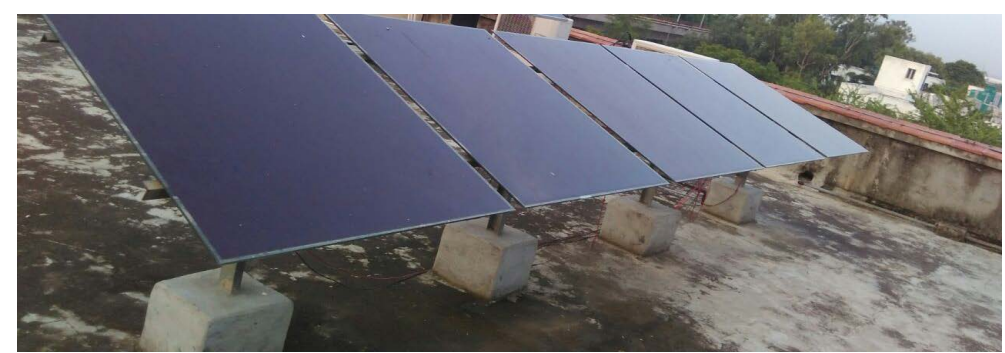

Figure 3. Cadmium telluride.

that an electrical difference builds up between the system and ground, as the frame is earthed for safety reasons. If the potential is negative (that is, the cell has more electrons relative to the ground), it creates a current that flows from the module frame to the PV cells, known as a leakage current. If the local short circuit occurred within only a single p-n junction, it would not be a problem. However, it happens in multiple $\mathrm{p}-\mathrm{n}$ junctions. This reduces the maximum power point and the open circuit voltage, which in turn reduces the total string voltage. As a consequence, the inverter switches on later in the morning than it should because the solar array needs more radiation to reach the inverter's minimum voltage [10] [11] [12]. The inverter also switches off earlier in the evening, as the system voltage drops rapidly with the day's decreasing irradiance. PID also affects the output current because, as the leakage currents between the cells and the frame become greater, the output current reduces, which results in a bigger output loss. Once PID has affected the array, the modules become increasingly less effective and a loss of up to $70 \%$ can be measured. PID is caused by leakage currents created by the potential difference between the ground and the PV cells. Any factor that increases these leakage currents or the electrical potential (even indirectly) contributes to PID. This, therefore, also deserves attention. Contributing factors can be broken down into the three following areas: environmental, material and system design. It is important to note that these factors affect every installation and are considered to have the greatest impact on PID. The two principal environmental characteristics that affect how much leakage current will flow through the module are humidity and temperature. As the PV system is exposed to higher levels of relative humidity, water vapor penetrates the system and makes it more conductive. The sodium ions can move more easily inside the material, and more positive charge is accumulated on the 
top of the solar cell. As a consequence, leakage current intensifies and PID increases [13] [14] [15] [16]. A PV system is composed of many different elements. The qualities and properties of each one can determine how prone the cell is to PID. The main components of a module that influence degradation are the anti-reflective coating, the glass and the encapsulating material. The anti-reflective coating helps to increase the amount of light captured by the solar cell, which results in higher currents. However, depending on its thickness, refractive index and coating homogeneity, the anti-reflective coating affects PID in different ways. For example, the widely used anti-reflective coating silicon nitride ( $\mathrm{SiN}$ ) can accelerate the PID process when its layers accumulate highly mobile sodium ions [17] [18]. Researchers have shown that some types of glass are more susceptible to increased leakage currents than others. This is because certain glasses have high concentrations of sodium that can be released when the glass is exposed to moisture or high temperatures. Using a type of glass with less sodium (for example, quartz instead of soda-lime) can potentially reduce the PID susceptibility. Since humidity increases the conductivity of the PV system, how permeable the encapsulating material is also plays a crucial part in PID susceptibility. PID occurs when the system has a negative potential relative to the ground. A simple solution is to ground the negative pole of the array and make the system operate only in a positive potential, a process known as functional earthling. Excluding the case where the cell suffers electro-corrosion, this method works well. However, in the past few years, transformer less or non-isolated inverter technologies have been widely adopted, and these do not allow for functional earthling of the array. Another possible solution is to install a PV-offset box. During the night, this device applies a positive potential to the system, discharging any particles and reversing the polarization effect [19] [20] [21]. Figure 1, Figure 2 and Figure 3 show the monocrystalline, polycrystalline and Cadmium Telluride solar modules installed on the roof top of engineering building.

\section{Degradation Analysis}

The solar plant comprises of 20 numbers of solar panel, of cumulative capacity of $2 \mathrm{~kW}$ and a weather station. (Table $1 \&$ Table 2)

$T_{\text {stc }}=$ Standard Operating Temperature $=25^{\circ} \mathrm{C}$

$T_{\text {actual }}=$ Actual operating Temperature

$\Delta T=T_{\text {stc }}-T_{\text {actual }}$

$V_{\text {decrease }}=$ Output Voltage Decreased by $2.3 \mathrm{mv} /{ }^{\circ} \mathrm{C}$

$P_{\max }=$ maximum power

Reduced output voltage $=V_{o c}\left(25^{\circ} \mathrm{C}\right)-\left(V_{\text {decrease }} \times \Delta T\right)$

Cell efficiency at Temperature $(T)=$ Cell Efficiency at STC-Decrease in cell Efficiency due to temperature

$$
\begin{aligned}
& \text { Actual } P_{\max }=P_{\max }(\mathrm{STC})-0.45 \% /{ }^{\circ} \mathrm{C} \times P_{\max } \times \Delta T \\
& \text { Fill Factor }(F F)=\frac{I_{m} \times V_{m}}{I_{s c} \times V_{o c}}
\end{aligned}
$$


Table 1. Technical specification of solar PV modules installed on roof of electrical engineering department, JMI building.

\begin{tabular}{ccccccc}
\hline Type & $\begin{array}{c}\text { Maximum } \\
\text { Power }(\mathrm{Wp})\end{array}$ & $\begin{array}{c}\text { Voltage at Maximum } \\
\text { Power (V) }\end{array}$ & $\begin{array}{c}\text { Current at Maximum } \\
\text { Power (A) }\end{array}$ & $\begin{array}{c}\text { Open Circuit } \\
\text { Voltage (V) }\end{array}$ & $\begin{array}{c}\text { Short Circuit } \\
\text { Current (A) }\end{array}$ & $\begin{array}{c}\text { Tolerance } \\
\text { Mono crystalline }\end{array}$ \\
100 & 17.7 & 5.7 & 21.6 & 6.3 & $2 \%$ \\
Poly Crystalline & 100 & 17.7 & 5.7 & 21.6 & 6.3 & $2 \%$ \\
Thin plate & 100 & 17.7 & 5.7 & 21.6 & 6.3 & $2 \%$ \\
\hline
\end{tabular}

Table 2. Degradation factors of the solar panels.

\begin{tabular}{|c|c|c|c|c|c|c|c|c|}
\hline \multicolumn{4}{|c|}{ Year 2015} & \multicolumn{4}{|c|}{ Year 2016} & \multirow{2}{*}{$\begin{array}{c}\text { \% Degradation } \\
\text { factor }\end{array}$} \\
\hline $\operatorname{Temp}\left({ }^{\circ} \mathrm{C}\right)$ & $\begin{array}{l}\text { Solar Irradiation } \\
\mathrm{w} / \mathrm{m}^{2}\end{array}$ & \% Efficiency & Date & $\begin{array}{l}\text { Temp } \\
\left({ }^{\circ} \mathrm{C}\right)\end{array}$ & $\begin{array}{l}\text { Solar Irradiation } \\
\mathrm{w} / \mathrm{m}^{2}\end{array}$ & \% Efficiency & Date & \\
\hline 38.5 & 448.5 & 10.17 & 01-09-2015 & 38.5 & 458.2 & 10.074 & 02-09-2016 & 0.944 \\
\hline 31.9 & 210 & 10.61 & 03-09-2015 & 31.92 & 213.9 & 10.55 & 03-09-2016 & 0.566 \\
\hline 37.16 & 520.8 & 10.17 & 04-09-2016 & 37.19 & 515 & 10.1 & 04-09-2016 & 0.688 \\
\hline 42.25 & 751 & 9.965 & 06-09-2015 & 42.22 & 642 & 9.91 & 08-09-2016 & 0.552 \\
\hline 45.1 & 492.4 & 9.76 & 07-09-2015 & 45.6 & 490 & 9.69 & $15-09-2016$ & 0.717 \\
\hline 41.27 & 415.7 & 10 & 08-09-2015 & 41.21 & 429 & 9.93 & 08-09-2016 & 0.700 \\
\hline 40.65 & 795.5 & 10.038 & $11-09-2015$ & 40.61 & 724.5 & 9.96 & $19-09-2016$ & 0.777 \\
\hline 36.84 & 200.8 & 10.088 & 20-09-2015 & 36.8 & 184 & 10 & 25-09-2016 & 0.872 \\
\hline 32.5 & 518 & 10 & $12-09-2015$ & 31.7 & 525 & 9.92 & $10-09-2016$ & 0.8 \\
\hline 36.2 & 558 & 10.35 & $15-09-2015$ & 36.8 & 565 & 10.28 & $17-09-2016$ & 0.676 \\
\hline 34.6 & 521 & 10.2 & $18-09-2015$ & 34.1 & 531 & 10.11 & $20-09-2016$ & 0.882 \\
\hline 40.2 & 680 & 10.8 & 23-09-2015 & 40.6 & 665 & 10.72 & $12-09-2016$ & 0.741 \\
\hline
\end{tabular}

Output Power $\left(P_{\text {out }}\right)=I_{\text {sc }} \times V_{\text {oc }} \times F F$

Input Power $\left(P_{i n}\right)=$ Solar radiant power $\times$ Area

Efficiencyat temperature $T=$ Efficiency at $25^{\circ} \mathrm{C}($ STC $)$

$$
-\frac{0.45 \times \Delta T \times \text { efficiency at } 25^{\circ} \mathrm{C}}{100}
$$

Changed in efficiency per degree Centigrade Rise in Cell Temperature from standard test conditions (STC) value of $25^{\circ} \mathrm{C}$ is $-45 \%$.

Changed in Voltage per degree Centigrade Rise in Cell Temperature from standard test conditions (STC) value of $25^{\circ} \mathrm{C}$ is $-2.3 \mathrm{mV}$.

\section{Results and Conclusion}

The payback time is usually $20-25$ years, from the efficiency calculation of the panels; it has been shown that, the efficiency of the panel decreases as the life of panel increases. The efficiency of the panel also depends on pollution, particulate material (PM) accumulated on the surface; the efficiency generally reduces by 


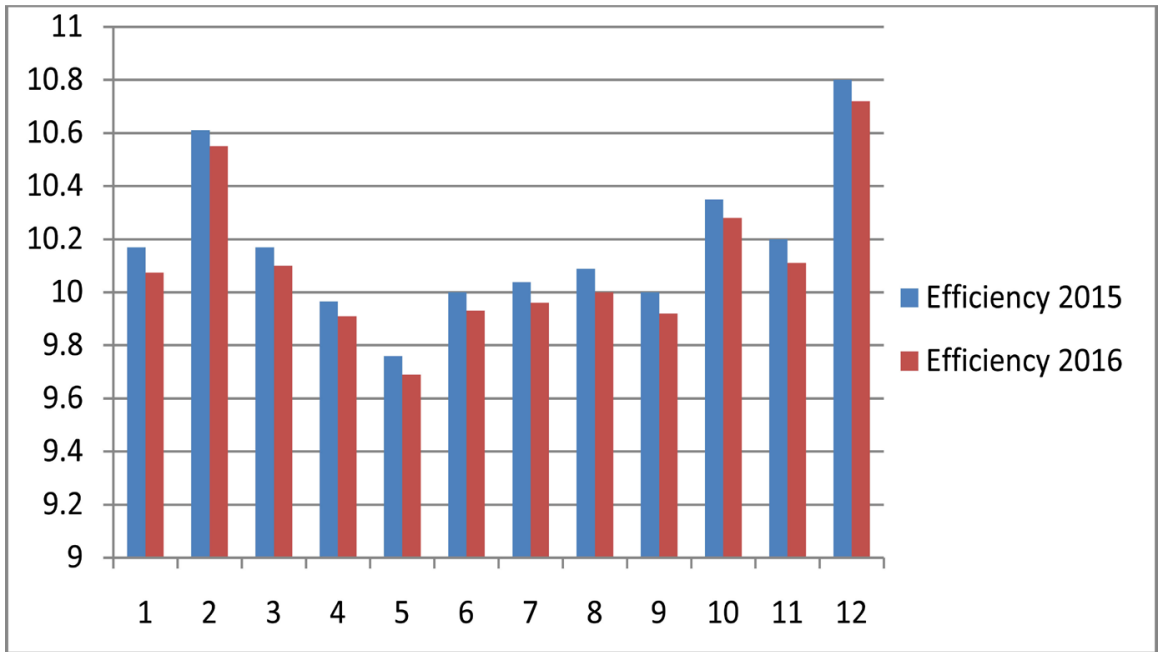

Figure 4. Graphical representation of efficiency of year 2015 \& 2016.

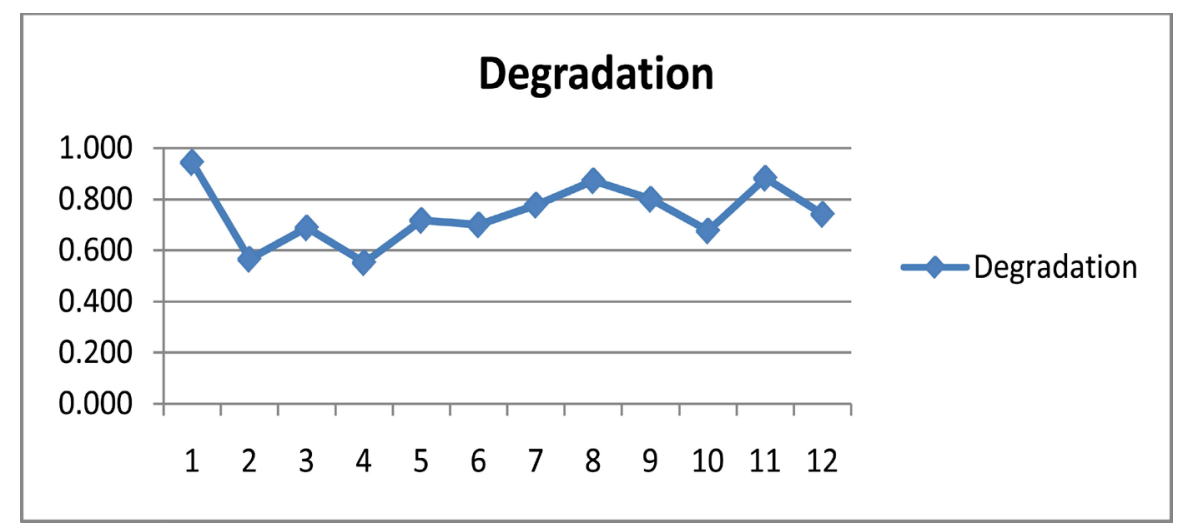

Figure 5. Graphical representation of degradation factor.

$17 \%-25 \%$ annually due to pollutants and PM. The rate of degradation varies between $0.55-0.95$ percent per year (Figure 4 \& Figure 5).

The data taken from the weather station and data logger 455B/24 channels in September 2015 and September 2016 have been analysed. The efficiency and degradation factor have been calculated and shown in Tabular form. Following results have been concluded from this analysis:

i) In September 2016, the minimum efficiency corresponds to solar irradiance $490 \mathrm{~W} / \mathrm{m}^{2}$ and temperature $45.6^{\circ} \mathrm{C}$. The maximum efficiency is $10.72 \%$ corresponding to solar irradiance $665 \mathrm{~W} / \mathrm{m}^{2}$ and temperature $40.6^{\circ} \mathrm{C}$.

ii) In September 2015, the efficiency varies between $9.76 \%$ to $10.8 \%$ which corresponds to different values of irradiance and temperature.

iii) From the efficiency calculation of the panels; it has been shown that, the efficiency of the panel decreases as the life of panel increases. The payback time is usually 20 - 25 years.

iv) The efficiency of the panel also depends on pollution, particulate material (PM) accumulated on the surface; the efficiency generally reduces by $17 \%$ $25 \%$ annually due to pollutants and PM.

v) The rate of degradation varies between 0.55 - 0.95 percent per year. 


\section{References}

[1] Limmanee, A., Songtrai, S., Udomdachanut, N., Kaewniyompanit, S., Sato, Y., Nakaishi, M., Kittisontirak, S., Sriprapha, K. and Sakamoto, Y. (2017) Degradation Analysis of Photovoltaic Modules under Tropical Climatic Conditions and Its Impacts on LCOE. Renewable Energy, 102, 199-204. https://doi.org/10.1016/j.renene.2016.10.052

[2] Sharma, V. and Chandel, S.S. (2016) A Novel Study for Determining Early Life Degradation of Multi-Crystalline-Silicon Photovoltaic Modules Observed in Western Himalayan Indian Climatic Conditions. Solar Energy, 134, 32-44. https://doi.org/10.1016/j.solener.2016.04.023

[3] Balaska, A., Tahri, A., Tahri, F. and Stambouli, A.B. (2017) Performance Assessment of Five Different Photovoltaic Module Technologies under Outdoor Conditions in Algeria. Renewable Energy, 107, 53-60. https://doi.org/10.1016/j.renene.2017.01.057

[4] Silvestre, S., Kichou, S., Guglielminotti, L., Nofuentes, G. and Alonso-Abella, M. (2016) Degradation Analysis of Thin Film Photovoltaic Modules under Outdoor Long Term Exposure in Spanish Continental Climate Conditions. Solar Energy, 139, 599-607. https://doi.org/10.1016/j.solener.2016.10.030

[5] Limmanee, A., Udomdachanut, N., Songtrai, S., Kaewniyompanit, S., Sato, Y., Nakaishi, M., Kittisontirak, S., Sriprapha, K. and Sakamoto, Y. (2016) Field Performance and Degradation Rates of Different Types of Photovoltaic Modules: A Case Study in Thailand. Renewable Energy, 89, 12-17.

https://doi.org/10.1016/j.renene.2015.11.088

[6] Bouraiou, A., Hamouda, M., Chaker, A., Mostefaoui, M., Lachtar, S., Sadok, M., Boutasseta, N., Othmani, M. and Issam, A. (2015) Analysis and Evaluation of the Impact of Climatic Conditions on the Photovoltaic Modules Performance in the Desert Environment. Energy Conversion and Management, 106, 1345-1355. https://doi.org/10.1016/j.enconman.2015.10.073

[7] Rajput, P., Tiwari, G.N. and Sastry, O.S. (2016) Thermal Modelling and Experimental Validation of Hot Spot in Crystalline Silicon Photovoltaic Modules for Real Outdoor Condition. Solar Energy, 139, 569-580. https://doi.org/10.1016/j.enconman.2015.10.073

[8] Park, N.C., Han, C.W. and Kim, D.H. (2013) Effect of Moisture Condensation on Long-Term Reliability of Crystalline Silicon Photovoltaic Modules. Microelectronics Reliability, 53, 1922-1926. https://doi.org/10.1016/j.microrel.2013.05.004

[9] Tanesab, J., Parlevliet, D., Whale, J., Urmee, T. and Pryor, T. (2015) The Contribution of Dust to Performance Degradation of PV Modules in a Temperate Climate Zone. Solar Energy, 120, 147-157. https://doi.org/10.1016/j.solener.2015.06.052

[10] Tossa, A., Soro, Y.M., Thiaw, L., Azoumah, Y., Sicot, L., Yamegueu, D., Lishou, C., Coulibaly, Y. and Razongles, G. (2016) Energy Performance of Different Silicon Photovoltaic Technologies under Hot and Harsh Climate. Energy, 103, 261-270. https://doi.org/10.1016/j.energy.2016.02.133

[11] Dabou, R., Bouchafaa, F., Arab, A.H., Bouraiou, A., Draou, M.D., Neçaibia, A. and Mostefaoui, M. (2016) Monitoring and Performance Analysis of Grid Connected Photovoltaic under Different Climatic Conditions in South Algeria. Energy Conversion and Management, 130, 200-206. https://doi.org/10.1016/j.enconman.2016.10.058

[12] Abderrezek, M. and Fathi, M. (2017) Experimental Study of the Dust Effect on Photovoltaic Panels' Energy Yield. Solar Energy, 142, 308-320. https://doi.org/10.1016/j.solener.2016.12.040 
[13] Attari, K., Elyaakoubi, A. and Asselman, A. (2016) Performance Analysis and Investigation of a Grid-Connected Photovoltaic Installation in Morocco. Energy Reports, 2, 261-266. https://doi.org/10.1016/j.egyr.2016.10.004

[14] Shukla, A.K., Sudhakar, K. and Baredar, P. (2016) Simulation and Performance Analysis of $110 \mathrm{~kW}_{\mathrm{p}}$ Grid-Connected Photovoltaic System for Residential Building in India: A Comparative Analysis of Various PV Technology. Energy Reports, 2, 82-88. https://doi.org/10.1016/j.egyr.2016.04.001

[15] Savvakis, N. and Tsoutsos, T. (2015) Performance Assessment of a Thin Film Photovoltaic System under Actual Mediterranean Climate Conditions in the Island of Crete. Energy, 90, 1435-1455. https://doi.org/10.1016/j.energy.2015.06.098

[16] Ferrada, P., Araya, F., Marzo, A. and Fuentealba, E. (2015) Performance Analysis of Photovoltaic Systems of Two Different Technologies in a Coastal Desert Climate Zone of Chile. Solar Energy, 114, 356-363.

https://doi.org/10.1016/j.solener.2015.02.009

[17] Wang, H.X., Muñoz-García, M.A., Moreda, G.P. and Alonso-García, M.C. (2017) Seasonal Performance Comparison of Three Grid Connected Photovoltaic Systems Based on Different Technologies Operating under the Same Conditions. Solar Energy, 144, 798-807. https://doi.org/10.1016/j.solener.2017.02.006

[18] Ioannou, A.K., Stefanakis, N.E. and Boudouvis, A.G. (2014) Design Optimization of Residential Grid-Connected Photovoltaics on Rooftops. Energy and Buildings, 76, 588-596. https://doi.org/10.1016/j.enbuild.2014.03.019

[19] Cristaldi, L., Faifer, M., Rossi, M., Toscani, S., Catelani, M., Ciani, L. and Lazzaroni, M. (2014) Simplified Method for Evaluating the Effects of Dust and Aging on Photovoltaic Panels. Measurement, 54, 207-214. https://doi.org/10.1016/j.measurement.2014.03.001

[20] Sharma, V., Kumar, A., Sastry, O.S. and Chandel, S.S. (2013) Performance Assessment of Different Solar Photovoltaic Technologies under Similar Outdoor Conditions. Energy, 58, 511-518. https://doi.org/10.1016/j.energy.2013.05.068

[21] Paudyal, B.R. and Shakya, S.R. (2016) Dust Accumulation Effects on Efficiency of Solar PV Modules for off Grid Purpose: A Case Study of Kathmandu. Solar Energy, 135, 103-110. https://doi.org/10.1016/j.solener.2016.05.046

\section{Submit or recommend next manuscript to SCIRP and we will provide best service for you:}

Accepting pre-submission inquiries through Email, Facebook, LinkedIn, Twitter, etc. A wide selection of journals (inclusive of 9 subjects, more than 200 journals)

Providing 24-hour high-quality service

User-friendly online submission system

Fair and swift peer-review system

Efficient typesetting and proofreading procedure

Display of the result of downloads and visits, as well as the number of cited articles

Maximum dissemination of your research work

Submit your manuscript at: http://papersubmission.scirp.org/

Or contact sgre@scirp.org 